\title{
Loch Lomond Stadial (Younger Dryas) glaciers and climate in Wales
}

\author{
PHILIP D. HUGHES* \\ School of Environment and Development, The University of Manchester, \\ Oxford Road, Manchester, UK
}

\begin{abstract}
Former cirque glaciers in the Aran and Berwyn mountains, North Wales, indicate a cold and wet climate during the Loch Lomond Stadial (Younger Dryas), with values of annual accumulation close to modern values of precipitation. Climate at the equilibrium line altitude (ELA) of these glaciers was reconstructed using a simple degree-day melt model and a regression relationship between summer precipitation + winter balance. These different approaches utilized published palaeoecological proxy data to isolate summer temperature and annual temperature range, in order to reconstruct values of annual accumulation and summer precipitation + winter balance. The degree-day model predicts that annual accumulation of 1920-2586 mm water equivalent (w.e.) would have been required to offset ablation, whilst the regression approach predicts a value of 2428-2985 mm w.e. for summer precipitation + winter balance. The degree of divergence between values of annual accumulation and summer precipitation + winter balance calculated by the two approaches depends on summer temperatures and also annual temperature range, which effectively determine the proportion of precipitation that falls as rain or snow. Copyright (C) 2009 John Wiley \& Sons, Ltd.
\end{abstract}

Received 13 October 2008; accepted 18 March 2009

KEY WORDS glaciers; palaeoclimate; Younger Dryas; degree-day model; mass balance; Arans; Berwyns; North Wales

\section{INTRODUCTION}

The last glaciers of Wales are commonly attributed to the Loch Lomond Stadial (Younger Dryas), at the end of the Pleistocene Late-glacial substage, between $c .11$ and $10{ }^{14} \mathrm{C}$ ka BP (Gray 1982; Lowe 1993; Shakesby and Matthews 1993; Carr 2001; Hughes 2002) and the timing of glaciation has been confirmed in some places using radiocarbon dating (Walker 1978; Walker 1980; Ince 1983, 1990) and also cosmogenic isotope analyses (Phillips et al. 1994). Evans (2006) noted that for 83 cirques across Wales there was uncertainty over whether they were occupied during the Loch Lomond Stadial, pending considerable further fieldwork. The paper presented here contributes to this need for further fieldwork and describes evidence of new sites in North Wales in the Arans and Berwyn mountains. Most of these sites have never been documented, with the exception of Llyn Lliwbran in the Arans (Hughes 2002) and only one site in the Berwyns, Llyn Lluncaws, has received a passing remark in previous literature (Travis 1944; Evans 2006).

Previous research investigating Loch Lomond Stadial glaciers in the British Isles have utilized linear regression or exponential power relationships between summer temperature and accumulation to reconstruct the climates at the equilibrium line altitudes (ELAs) of former glaciers (e.g. Ballantyne 1989, 2007a; Hughes 2002; Benn and Ballantyne 2005). Recent research has shown that a single accumulation-temperature relationship is not suitable for all climatic regions. Different accumulation-temperature relationships can exist depending upon the annual temperature range, representing the contrast between maritime and continental climates (Hughes and Braithwaite 2008; Braithwaite 2008).

* Correspondence to: Dr P. D. Hughes, School of Environment and Development, Arthur Lewis Building, The University of Manchester, Manchester M13 9PL, UK. E-mail: philip.hughes@manchester.ac.uk 
This paper has three main aims: (1) to examine evidence for local cirque glaciation in the Aran and Berwyn mountains; (2) to reconstruct glaciers based on the geomorphological evidence and (3) to examine two different approaches for reconstructing climates at the former ELAs of these glaciers. This last aim involved applying regression and degree-day model approaches to glacier-climate reconstruction and the findings have wider significance for the reconstruction of former glaciers and climates around the world.

\section{STUDY AREA}

The Arans are situated in Snowdonia National Park, North Wales (Figure 1), and are dominated by a ridge of Ordovician volcanic rocks. The eastern flank of the Aran ridge is composed of Ordovician slates and shales. The paper focuses on the southern part of this mountain group, to the south of the highest summit Aran Fawddwy $(905 \mathrm{~m})$ - earlier investigations of the northern area are reported in Hughes (2002). The Berwyns are situated c. $20 \mathrm{~km}$ to the northeast of the main Aran ridge (Figure 1), outside the Snowdonia National Park. Large areas of the Berwyns are formed of Ordovician and Silurian shales, slates, mudstones and sandstones with narrow intrusive rocks, such as the sill of dolerite on the summit of Cadair Berwyn (831 m) (Lomas 1908; Cope 1915).

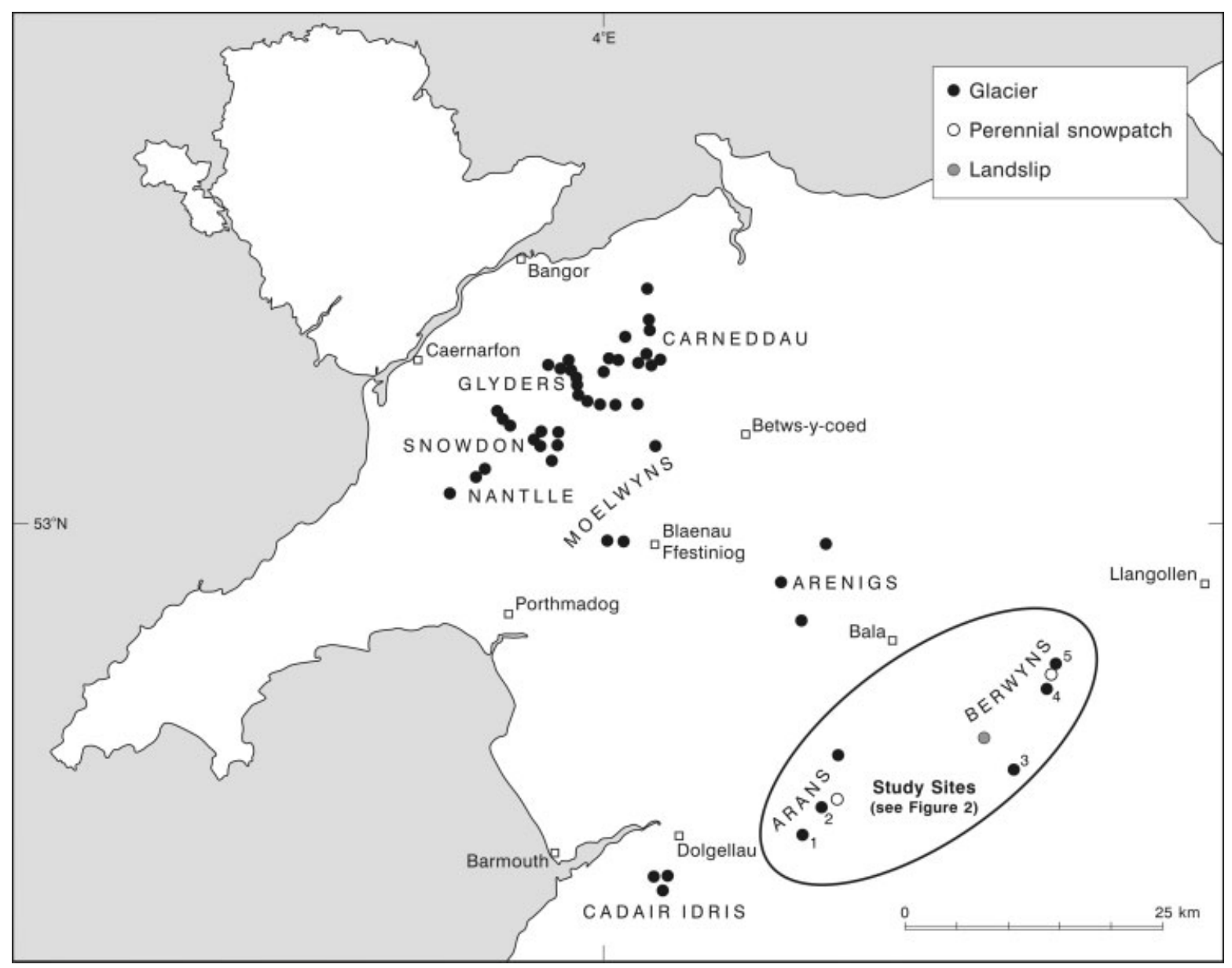

Figure 1. Location of the Arans and Berwyns in North Wales illustrating the distribution of former local glaciers and snow patches. Sites are numbered in accordance with Figure 3. 


\section{METHODS}

\subsection{Field methods}

Geomorphological mapping in the field was undertaken using 1:10000 base maps at potential sites of local glacier occupation identified beforehand, based on topographic maps and aerial photographs. Glacial features mapped included moraines and associated ridge crests, glacial lakes and cirques. The sedimentology of landforms was examined at some sites in order to differentiate between true glacial forms and other similar landforms that have very different origins such as landslides and pronival ramparts (sediment ridges formed in front of perennial snow patches). Natural exposures were utilized for sedimentological analyses, which included measurements of clast aaxis fabric, clast roundness and observations of clast features such as striae. The most detailed analyses were carried out where, on the basis of morphological criteria alone, a glacial origin is perhaps debatable.

\subsection{Glacier reconstruction}

In this study, several different methods of reconstructing glacier ELAs were used and the mean taken as representative of the ELA of the former glaciers. The methods included: the area-weighted mean altitude method (Sissons 1974); application of an accumulation area ratio of 0.6 (Porter 1975); application of a toe to headwall ratio of 0.4 (Harrison et al. 2006) and application of a balance ratio of 2 (Furbish and Andrews 1984; Benn and Ballantyne 2005; Ballantyne 2007a,b).

The potential effects of windblown snow can be quantified using a snowblow ratio (Sissons and Sutherland 1976; Mitchell 1988; Dahl et al. 1997). In this study, the snowblow ratio is defined as the ratio between the drainage area leading on to the accumulation area of the former glaciers (D) and the accumulation area of the glacier (A). Based on the assumption that precipitation was largely associated with Atlantic depressions and associated with winds from the south and west during the last phase of glaciation in the British Isles (Sissons 1979; Ballantyne 2002, $2007 \mathrm{a}, \mathrm{b}$ ), then only that part of the drainage area between 180 and $270^{\circ}$ leading directly on to the glacier was used to calculate $\mathrm{D}$.

\subsection{Glacier-climate reconstruction}

Two approaches were taken to reconstruct climate at the ELAs of the former glaciers in the Arans and Berwyns. One utilized a degree-day model approach and the other utilized a regression between summer precipitation + winter balance and summer temperature.

A simple degree-day model was used to calculate the amount of accumulation required to sustain glaciers, in the Aran and Berwyn mountains. This approach is based on calculations of daily melt as a function of daily mean temperatures for each day of the year. Mean annual temperatures can be distributed over a sine curve to provide daily temperature means using the following equation (from Brugger 2006):

$$
\mathrm{T}_{\mathrm{d}}=A_{\mathrm{y}} \sin \left(\frac{2 \pi \mathrm{d}}{\lambda-\Phi}\right)+\mathrm{T}_{\mathrm{a}}
$$

where $\mathrm{T}_{\mathrm{d}}$ is the mean daily air temperature, $A_{\mathrm{y}}$ the amplitude of the yearly temperature $(1 / 2$ of the annual temperature range), $\mathrm{d}$ the ordinal day (1-365), $\lambda$ the period (365 days), $\Phi$ the phase angle (taken as 1.93 to reflect the fact that January is the coolest month) and $\mathrm{T}_{\mathrm{a}}$ is the mean annual air temperature. The amount of snow melt per day can then be calculated using a degree-day factor of $4 \mathrm{~mm}_{\text {day }}{ }^{-1}{ }^{\circ} \mathrm{K}^{-1}$ (Braithwaite et al. 2006) and the annual accumulation required at the ELA to balance melting equals the annual sum of daily snow melt.

Two inputs are required in order to apply the degree-day model to reconstruct climate at the ELA of the Loch Lomond Stadial glaciers: mean annual air temperature and annual temperature range. At Llanilid in South Wales, Walker et al. (2003) suggested that mean July temperature values were $10-11^{\circ} \mathrm{C}$ during the Loch Lomond Stadial 
based on Coleopteran data. Thus, a July mean of $10.5^{\circ} \mathrm{C}$ was assumed and this was distributed over 12 months of the year using a defined annual range, in order to obtain a value of mean annual temperature.

Annual temperature range is crucial when using a single monthly mean temperature, such as for July, to calculate a mean for a set of other months, whether that be mean annual temperature or mean summer temperature. Annual temperature range is also crucial when modelling snow melt, as illustrated by Hughes and Braithwaite (2008) (Figure 2). Other glacial studies in the British Isles have assumed a modern analogue from Scotland and Scandinavia for annual temperature range during the Loch Lomond Stadial (e.g. Benn and Ballantyne 2005). However, based on biological and geomorphological evidence across Europe, Isarin et al. (1998, their figure 4) suggested that the annual range of mean monthly temperatures in England and Wales during the Loch Lomond Stadial was $30-34^{\circ} \mathrm{C}$, which is $18-22^{\circ} \mathrm{C}$ greater than the modern annual range. Sea levels were lower in this area during the Loch Lomond Stadial (Shennan and Horton 2002) revealing a large area of continental shelf off the coast of Wales. Furthermore the North Atlantic would have frozen during the winter months - a situation promoted by a shut down of thermohaline circulation (Bradley and England 2008) and the position of Britain, north of the Polar Front, which was situated to the southwest of the British Isles at this time (Ruddimann and McIntyre 1981). These factors would have caused a greater contrast between winter and summer temperatures than is the case today, as is indicated in the evidence used in the model of Isarin et al. (1998). So, a sea-level July mean of $10.5^{\circ} \mathrm{C}$ during the Loch Lomond Stadial was distributed over an annual range of $30^{\circ} \mathrm{C}$ to obtain the mean annual temperature. This temperature was then extrapolated to the lowest and highest ELAs of the Aran and Arenig glaciers using a lapse rate of $0.6^{\circ} \mathrm{C} / 100 \mathrm{~m}$. The accumulation required to balance melting was then calculated for each day of the year using Equation (1) and summed over the whole year to give the annual accumulation.

A second approach utilized the empirical relationship between summer temperature and summer precipitation + winter balance defined by a regression in Ohmura et al. (1992)

$$
\mathrm{P}=645+296 \mathrm{~T}+9 \mathrm{~T}^{2}
$$

where $\mathrm{P}=$ winter balance + summer precipitation (metres water equivalent (w.e.)) and $\mathrm{T}=$ mean summer temperature in ${ }^{\circ} \mathrm{C}$ (June/July/August). As described above, a sea-level July mean of $10.5^{\circ} \mathrm{C}$ during the Loch
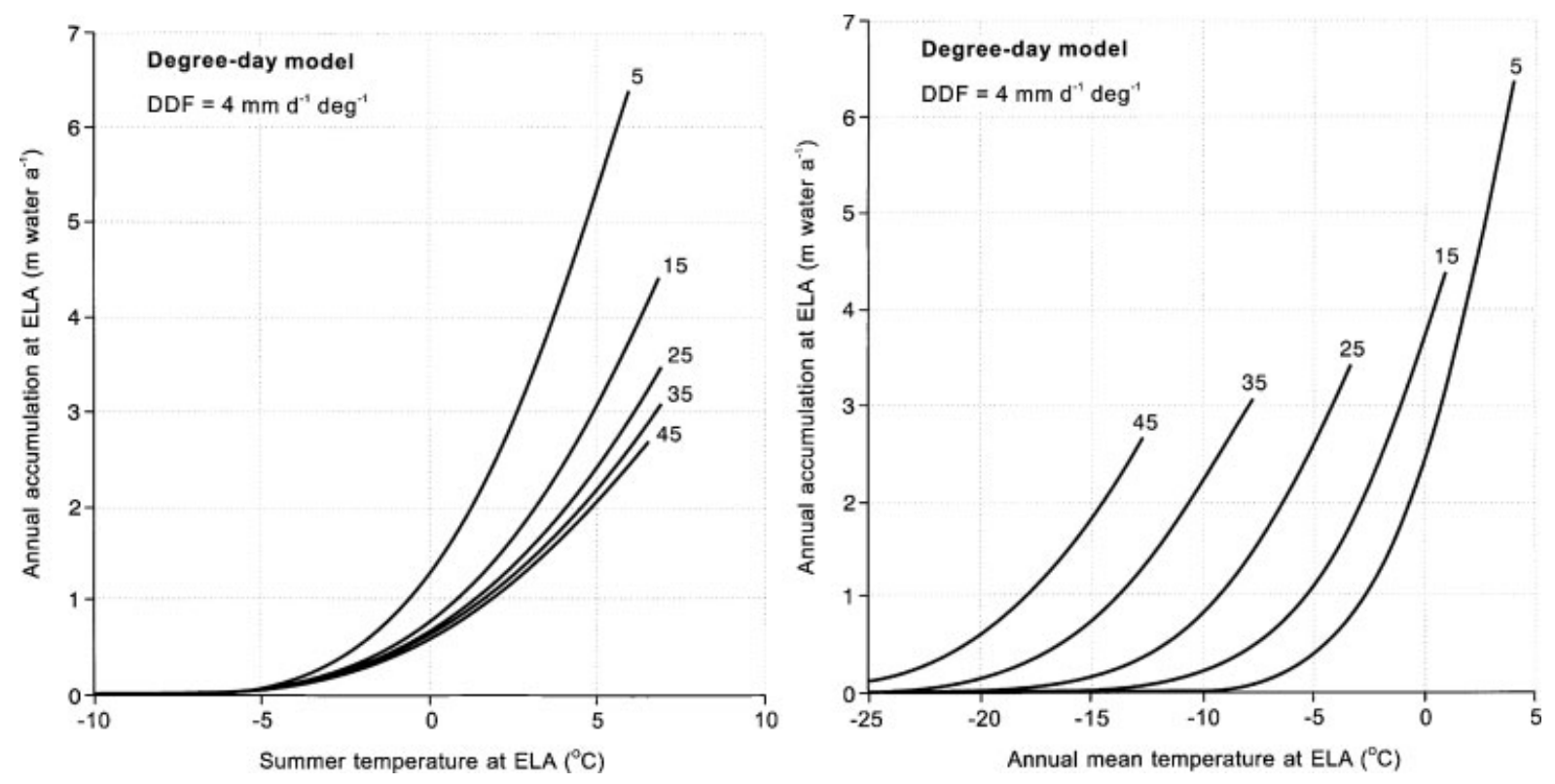

Figure 2. Annual accumulation at the equilibrium line altitude (ELA) as a function of summer mean temperature (June-August) and mean annual temperature (January-December). The degree-day model was applied assuming a sinusoidal temperature variation throughout the year with annual temperature ranges of 5, 15, 25, 35 and $45^{\circ} \mathrm{C}$ (from Hughes and Braithwaite 2008). 
Lomond Stadial was extrapolated to the former ELAs of the Aran and Berwyn glaciers using a lapse rate of $0.6^{\circ} \mathrm{C} /$ $100 \mathrm{~m}$. A summer mean (JJA) at the ELA was then obtained based on the distribution of temperatures over the year with a July mean of $10.5^{\circ} \mathrm{C}$ and an annual range of $30^{\circ} \mathrm{C}$. This was then input into Equation (2) to calculate a value for summer precipitation + winter balance.

\section{GEOMORPHOLOGICAL EVIDENCE: RESULTS AND INTERPRETATION}

\subsection{Arans}

A well-defined northeast-facing arcuate hollow with a steep backwall and a gentle floor is present at the head of Cwm Cywarch between the peaks of Y Gribin (602 m) and Glasgwm (779 m) (Grid reference: SH843183). Clear arcuate sediment ridges are present $150 \mathrm{~m}$ from the base of the backwall at an altitude of $c .460 \mathrm{~m}$ and enclose an area of flat boggy ground. The geomorphology of this site is consistent with local cirque glaciation with a welldefined cirque and very clear moraines (Figures 3 and 4).

Steep arcuate cliffs bound a northeast-facing hollow on the slopes of Gwaun-y-Llwyni $(685 \mathrm{~m})$ at the head of Hengwm (Grid reference: SH858206). The hollow floor has a gradient of $c .10^{\circ}$ and contains thick accumulations of muddy diamicton. Sediment analysis at one large section exposure revealed the diamicton to be dominated by subrounded (SA: $10 \%$; SR: 70\%; R: $20 \%)$ and striated clasts $(70 \%)$ and had a strong fabric $\left(\mathrm{S}_{1}: 0.65\right)$ dipping upvalley towards the headwall (mean lineation vector: $246^{\circ}$ ). These sediments form a clear ridge on the northwestern side of the hollow, which is clearly visible in the field and on aerial photographs. The hollow at Gwaun-y-Llwyni has all the attributes of a glacial cirque. The sediments on the floor of this cirque display clear glacial characteristics and the landforms are interpreted as localized moraines.

A northeast-facing hollow is present on the slopes of Drysgol $(731 \mathrm{~m})$ (Grid reference: SH874215). This has a steep backwall formed in Ordovician slates and with a gentler floor bounded by mounds of sediment. These mounds are situated less than $100 \mathrm{~m}$ from the backwall and clasts within the sediments are dominated by angular slates. Evans (2006) identified the hollow on Drysgol as a marginal cirque. However, the sediments on the floor of this cirque, and the short distance between the sediment ridge and the backwall, do not suggest formation by a local glacier and may represent either pronival ramparts or landslip/rock slope failure deposits. The aspect towards the northeast is consistent with the former.

In the northern Arans, Lowe (1993) and Hughes (2002) identified another former local glacier site at Llyn Lliwbran to the northeast of Aran Benllyn (Grid reference: SH875255). There are no other clear local glacier sites in the Arans. Elsewhere, the lake of Creiglyn Dyfi occupies a well-defined cirque (Evans 2006) but does not contain moraines. The lake is retained by a bedrock ridge, which is clearly exposed by the incision of the stream draining the lake.

\subsection{Berwyns}

Cwm Llawenog is a northeast-facing hollow to the south of Cadair Bronwen (784 m) (Grid reference: SJ078338). The headwall of this hollow consists of an arcuate line of steep cliffs formed in Ordovician mudstones. Numerous sediment ridges and mounds are present on the floor of this cirque down to $c .570 \mathrm{~m}$. In particular, a clear linear ridge runs from this altitude up to $c .690 \mathrm{~m}$ on the northwestern side of this hollow (Figure 5). Exposures in these sediments reveal a clast-rich muddy diamicton dominated by subrounded (SA: 20\%; SR: 60\%; R: 20\%) and striated clasts $(60 \%)$ with a strong fabric $\left(\mathrm{S}_{1}: 0.73\right)$ dipping up-valley towards the headwall (mean lineation vector: $\left.220^{\circ}\right)$. The geomorphology of Cwm Llawenog is consistent with local cirque glaciation with a well-defined cirque and associated moraines (Figures 3 and 5).

The headwall of Cwm Maen Gwynedd is dominated by east-facing cliffs of Craig Berwyn, which are over $1.5 \mathrm{~km}$ long. These cliffs are formed in Ordovician mudstones intercalated with a dolerite sill which runs along the highest parts of these cliffs (Travis 1944). Two linear sediment ridges are present at the base of these cliffs at altitudes of $c$. 620 and $660 \mathrm{~m}$ respectively, and are situated less than $100 \mathrm{~m}$ from the base of the backwall (Grid reference: SJ331076). The sediments are composed of a clast-rich muddy diamicton with angular to subangular clasts. There 

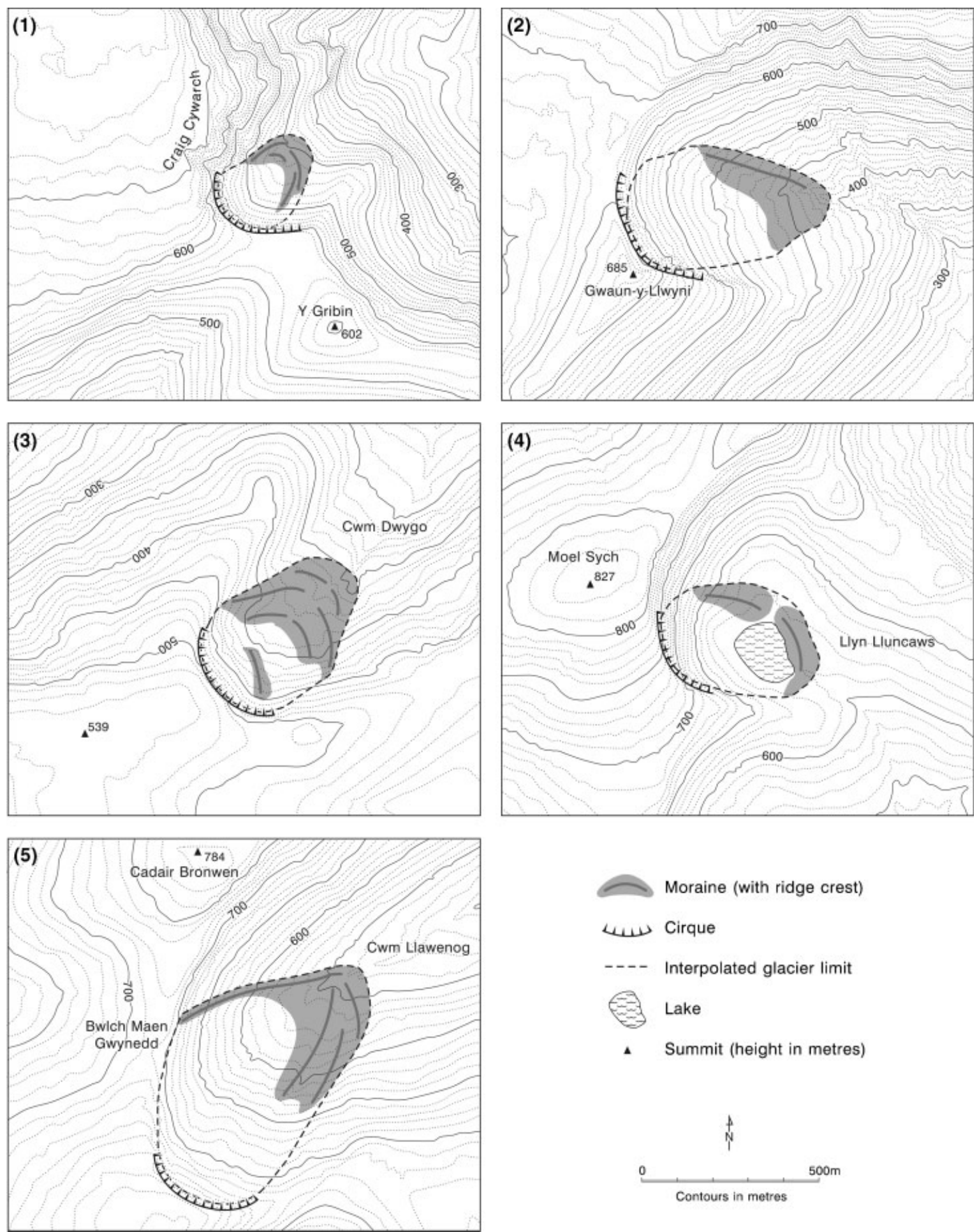

4. Summit (height in metres)

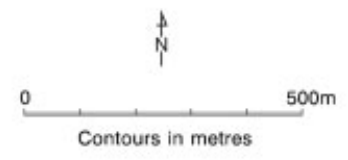

Figure 3. Geomorphological maps of (1) Y Gribin (Arans), (2) Gwaun-y-Llwyni (Arans), (3) Cwm Dwygo (Berwyns), (4) Llyn Lluncaws (Berwyns) and (5) Cwm Llawenog (Berwyns). 


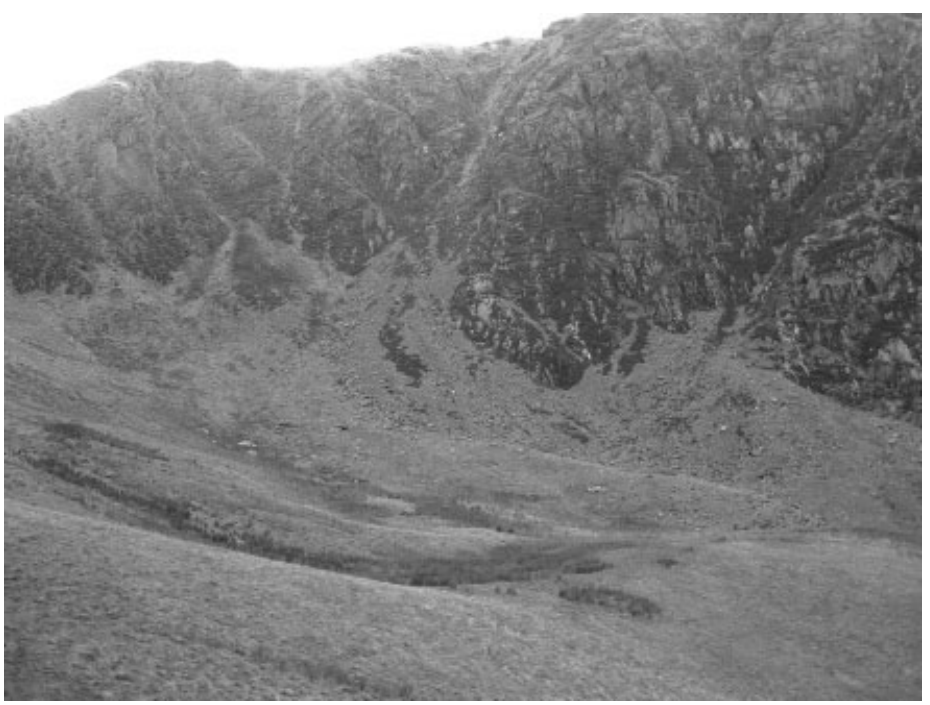

Figure 4. Moraines in the cirque of Y Gribin, at the head of Cwm Cywarch in the Arans (see Figure 3(1) for location). View looking southwest. All of the photographed sites, presented here and in Figures 5-7, are interpreted as local glacier sites with localized accumulations of moraines within cirques and attributed to climate cooling during the Loch Lomond Stadial —a situation in common with many other cirque sites in Wales.

is insufficient space between these ridges and the backwall for dynamic glacier ice to form and the lack of striated subrounded clasts also does not indicate clast transport beneath ice (Ballantyne and Benn 1994). Thus, these ridges could be interpreted as pronival ramparts or landslip/rockslope failure deposits, although the east-facing aspect is consistent with the former.

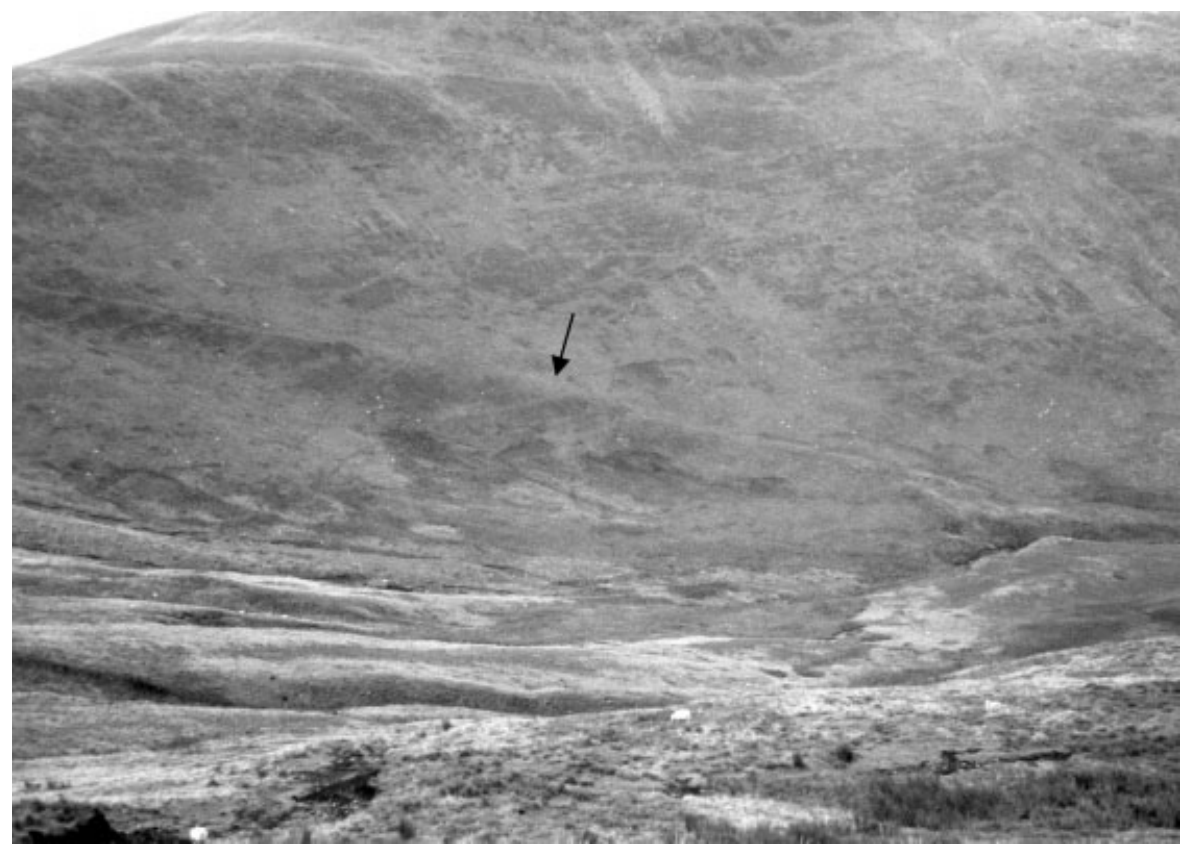

Figure 5. A linear sediment ridge (arrowed) running up the northwestern side of Cwm Llawenog (see Figure 3(5) for location). View looking northwest. This feature is interpreted as a lateral moraine of a former small cirque glacier. 
Llyn Lluncaws occupies an arcuate basin cut into the east-facing slopes of Moel Sych $(827 \mathrm{~m})$ (Grid reference: SJ072317). The steep basin headwall is formed in Ordovician mudstones, which is intercalated with outcrops of dolerite (Travis 1944). The lake is dammed by a thick accumulation of sediments on the eastern shores. The constituent sediments are exposed in stream cuttings to the south-east of the lake. The sediments consist of subrounded striated dolerite and mudstone boulders within a clast-rich muddy diamicton. The sediment forms a broad embankment with a very subdued form. A similar sediment accumulation is also present on the northern shores of the lake (Figure 6). These sediments are interpreted as moraines formed by a small glacier in this cirque. Evans (2006, figure 5) indicated that this cirque contains moraines of possible Late-glacial age and stated that Llyn Lluncaws occupies a 'classic' cirque. Another clear cirque is situated to the south of Llyn Lluncaws at SJ072312. However, moraines are not clearly visible on the floor of this cirque and it is uncertain whether it would have supported a local glacier at the same time as at Llyn Lluncaws.

Cwm Dwygo is a deep northeast-facing hollow in the Pennant valley near Llangynog (Grid reference: SJ040244). The hollow is backed by steep headwall cliffs formed in Ordovician siltstones and sandstones. Sediment mounds and ridges fill the floor of Cwm Dwygo down to an altitude of $c .350 \mathrm{~m}$ a.s.l. (Figure 7). Below the headwall cliffs, at $c .380 \mathrm{~m}$ a.s.l. these mounds and ridges enclose a flat bog surface. Stream sections through these mounds exposed a clast-rich muddy diamicton. Clasts were predominantly subrounded (SA: 30\%; SR: 50\%; R: $20 \%)$ and striated $(60 \%)$ and had a strong fabric $\left(\mathrm{S}_{1}: 0.63\right)$ dipping up-valley towards the headwall (mean lineation vector: $220^{\circ}$ ). Another sediment ridge is also situated close to the headwall. The morphometry of the low cirque at Cwm Dwygo is clearly consistent with the definition of a cirque suggested by Evans and Cox (1974, p. 151) but it was overlooked in Evans (2006). The presence of striated subrounded boulders on the surface of these mounds and ridges and the preferential dip of clasts within a muddy diamicton towards the headwall suggests a glacial origin for these deposits. In addition to the cirque floor moraines filling Cwm Dwygo a sediment ridge is also present close to the cirque backwall. This may either be a landslip/rockslope failure deposit or a pronival rampart formed after glacier occupation of this cirque.

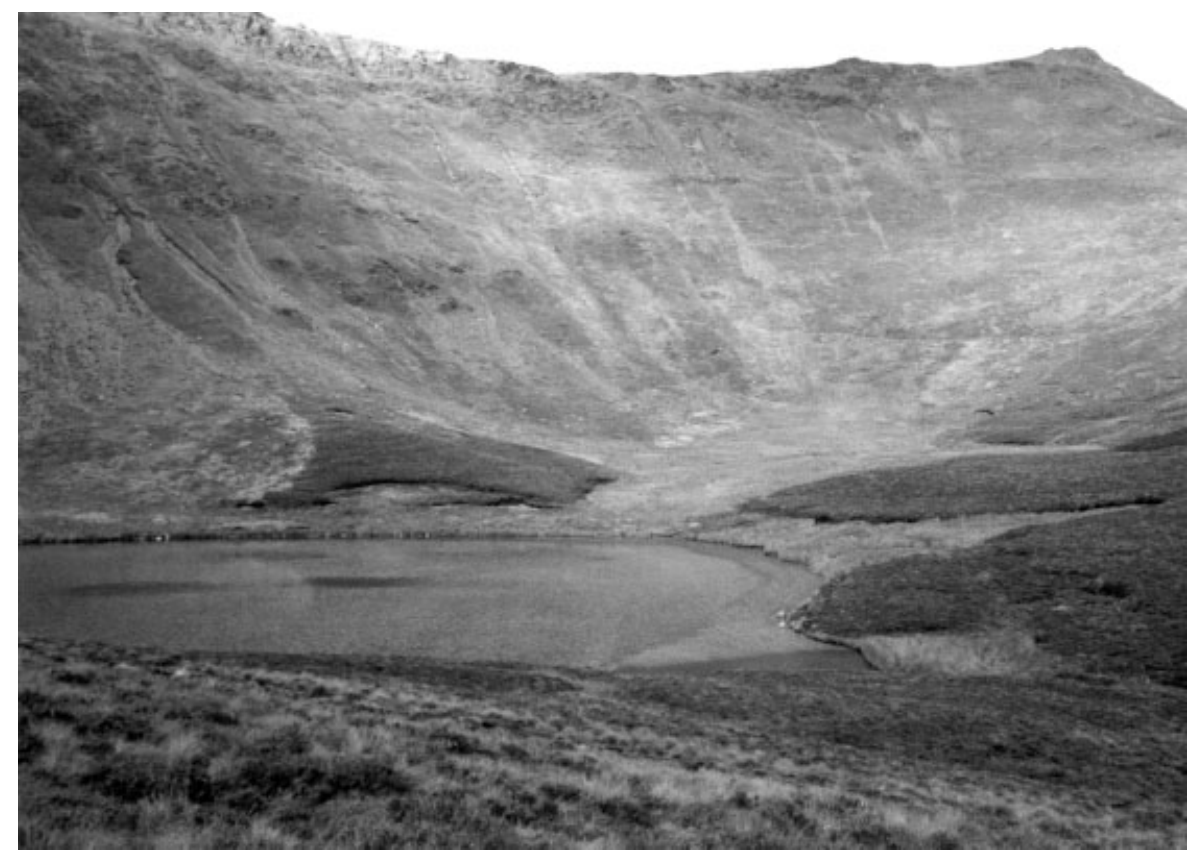

Figure 6. Llyn Lluncaws in the Berwyns (see Figure 3(4) for location). View looking northwest. The lake is dammed by subdued sediment ridges and mounds and backed by steep arcuate backwall cliffs. 


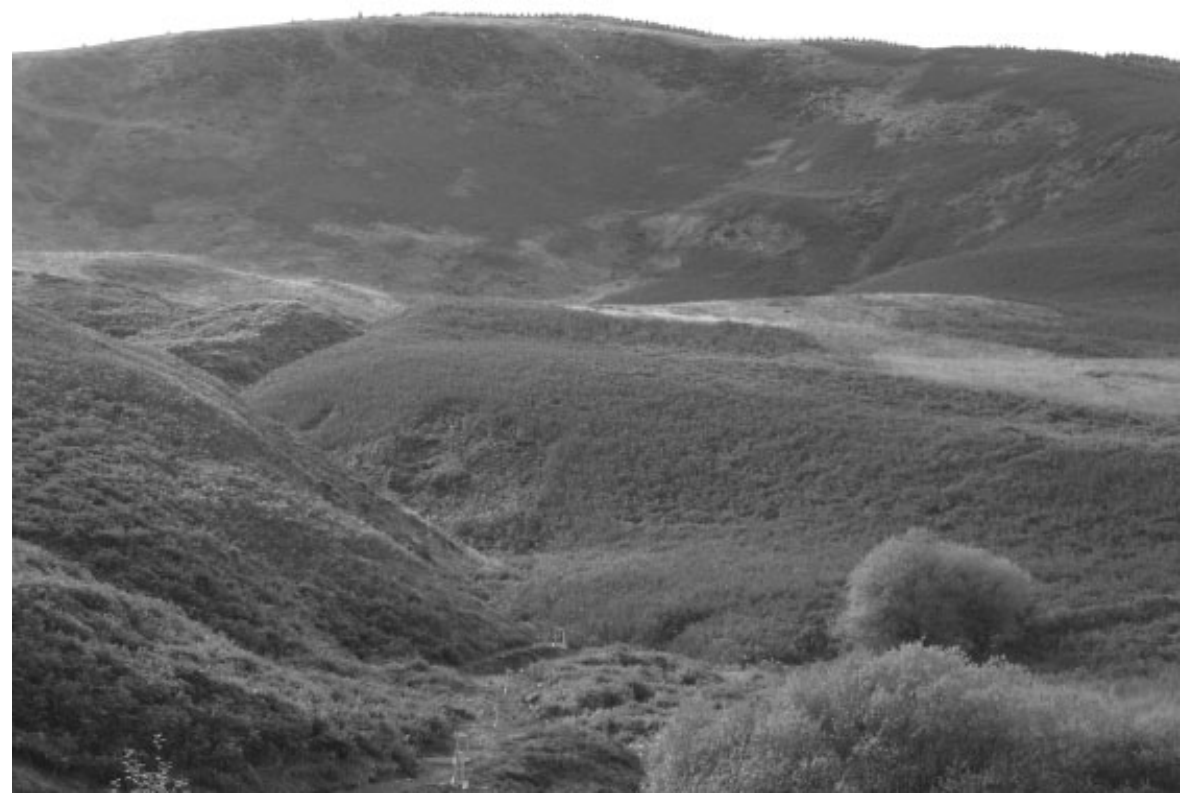

Figure 7. Cwm Dwygo illustrating the steep backwall and the sediment mounds and ridges on the hollow floor. (See Figure 3(3) for location.) View looking southwest.

An arcuate hollow backed by steep east-facing cliffs is also present at Blaen-y-Cwm at the head of Cwm Pennant (Grid reference: SJ012274). Mounds of sediment are present at the base of steep Ordovician siltstone and mudstone cliffs (Travis 1944, p. 25). Angular boulders rest on top of these mounds at an altitude of $c .250 \mathrm{~m}$ a.s.l. and the cliffs of Graig Wen to the south are cut by a deep scar. However, these mounds are situated at a much lower altitude ( $250 \mathrm{~m}$ a.s.l.) than moraines and pronival ramparts elsewhere in the Berwyns, especially those at Llyn Lluncaws and Cwm Llawenog. This, and the angularity of the surface clasts and geomorphological position of the deposits, suggests that the Blaen-y-Cwm sediment mounds were formed by a landslip or rock slope failure.

\section{GLACIER-CLIMATE RECONSTRUCTION: RESULTS}

The characteristics of the Aran and Berwyn cirque glaciers are displayed in Table 1. They ranged in size from 3.4 to 23.2 hectares $\left(0.034-0.232 \mathrm{~km}^{2}\right)$ reaching lengths of between 280 and $760 \mathrm{~m}$ and all had northeast-facing aspects.

Table 1. Characteristics of reconstructed cirque glaciers in the Arans and Berwyns, North Wales

\begin{tabular}{lccccc}
\hline Glacier & $\begin{array}{c}\text { Area } \\
\left(\mathrm{km}^{2}\right)\end{array}$ & $\begin{array}{c}\text { Ice depth at } \\
\text { the ELA }(\mathrm{m})\end{array}$ & $\begin{array}{c}\text { Total glacier } \\
\text { length }(\mathrm{m})\end{array}$ & $\begin{array}{c}\text { Snowblow } \\
\text { ratio }\end{array}$ & $\begin{array}{c}\text { Aspect } \\
(\text { degrees })\end{array}$ \\
\hline Y Gribin & 0.034 & 35 & 280 & 1.2 & 042 \\
Gwaun-y-Llwyni & 0.110 & 30 & 492 & 0.4 & 062 \\
Cwm Dwygo & 0.103 & 35 & 470 & 3.2 & 039 \\
Llyn Lluncaws & 0.104 & $40^{*}$ & 440 & 1.8 & 072 \\
Cwm Llawenog & 0.232 & 45 & 760 & 0.7 & 046 \\
\hline
\end{tabular}

${ }^{*}$ Minimum depths over lakes. 
Table 2. Values of reconstructed equilibrium line altitudes (ELAs) calculated using different approaches in the Arans and Berwyns, North Wales

\begin{tabular}{|c|c|c|c|c|c|}
\hline Glacier & MEG & $\mathrm{AAR}=0.6$ & THAR & $\mathrm{BR}=2$ & Mean ELA \\
\hline Y Gribin & 510 & 497 & 500 & 493 & 500 \\
\hline Gwaun-y-Llwyni & 516 & 505 & 510 & 503 & 509 \\
\hline Cwm Dwygo & 438 & 425 & 429 & 422 & 429 \\
\hline Llyn Lluncaws & 655 & 635 & 646 & 632 & 642 \\
\hline Cwm Llawenog & 675 & 655 & 660 & 651 & 660 \\
\hline
\end{tabular}

$\mathrm{AWMA}=$ area-weighted mean altitude, $\mathrm{AAR}=$ accumulation area ratio, $\mathrm{THAR}=$ toe-to-headwall ratio, $\mathrm{BR}=$ balance ratio

Different approaches to ELA calculation produced only a minor variation in values (Table 2), a consequence of the small altitudinal coverage of the former glaciers. ELAs calculated using the area-weighted mean approach were slightly higher than using other techniques, a characteristic of this technique recognized by Sutherland (1984).

The reconstructed climates at the ELA of the highest and lowest Aran and Berwyn glaciers (Cwm Llawenog $(660 \mathrm{~m})$ and Cwm Dwygo (429 m), respectively) calculated using the Ohmura et al. (1992) regression and a simple degree-day model are presented in Table 3. Summer temperature (June/July/August) at the ELA of the Aran and Berwyn glaciers ranged from 5.2 to $6.6^{\circ} \mathrm{C}$. For these values of summer temperature, the Ohmura et al. (1992) regression predicts values of between 2428 and $2985 \mathrm{~mm}$ (w.e.) for winter balance + summer precipitation. Alternatively, the degree-day model predicts values of between 1920 and $2586 \mathrm{~mm}$ (w.e.) for annual accumulation (Figure 8).

\section{DISCUSSION}

\subsection{Regional significance}

It is very likely that the cirque moraines in the Arans and Berwyns are the product of glacier formation during the Loch Lomond Stadial, in common with other cirque moraines across Wales. All of the glaciers were northeast- to east-facing $\left(039-072^{\circ}\right)$. They were at least $280 \mathrm{~m}$ long and moraines were always situated at least $150 \mathrm{~m}$ from the base of the backwall - well beyond the threshold for pronival ramparts (Ballantyne and Benn 1994) (Table 1).

The ELAs of the three Aran glaciers had a very limited range of 500-511 m (Table 2, and including the site at Llyn Lliwbran), which closely correspond with three glaciers in the Arenigs to the north (ELAs: 470-531 m) (Hughes 2002). However, all of these glaciers were lower than the glaciers on Cadair Idris to the west (560-622 $\mathrm{m}$ ) (Lowe 1993) and lower than the average glacier elevation in northern Snowdonia (600 m) (Gray 1982) (Table 4). The three Berwyn glaciers had a range skewed by the very low Cwm Dwygo glacier (429-660 m). The two easternmost glaciers at Llyn Lluncaws and Cwm Llawenog had ELAs well above those in the Arans and Arenigs

Table 3. Reconstructed climate combinations at the ELA of the highest and lowest Aran and Berwyn glaciers (Cwm Llawenog $(660 \mathrm{~m})$ and Cwm Dwygo (429 m), respectively) calculated using the Ohmura et al. (1992) regression and a simple degree-day model

\begin{tabular}{lcc}
\hline & $\begin{array}{c}\text { Ohmura } \text { et al. }(1992) \text { regression } \\
\text { winter balance }+ \text { summer } \\
\text { precipitation }(\mathrm{mm} \text { w.e. })\end{array}$ & $\begin{array}{c}\text { Degree-day model } \\
\text { annual accumulation } \\
\text { (mm w.e.) }\end{array}$ \\
\hline $\begin{array}{l}\text { Mean summer temperature of } 5.2^{\circ} \mathrm{C} \\
(\text { Cwm Llawenog, ELA }=660 \mathrm{~m})\end{array}$ & 2428 & 1920 \\
$\begin{array}{l}\text { Mean summer temperature of } 6.6^{\circ} \mathrm{C} \\
(\text { Cwm Dwygo, ELA }=429 \mathrm{~m})\end{array}$ & 2985 & 2586 \\
\hline
\end{tabular}




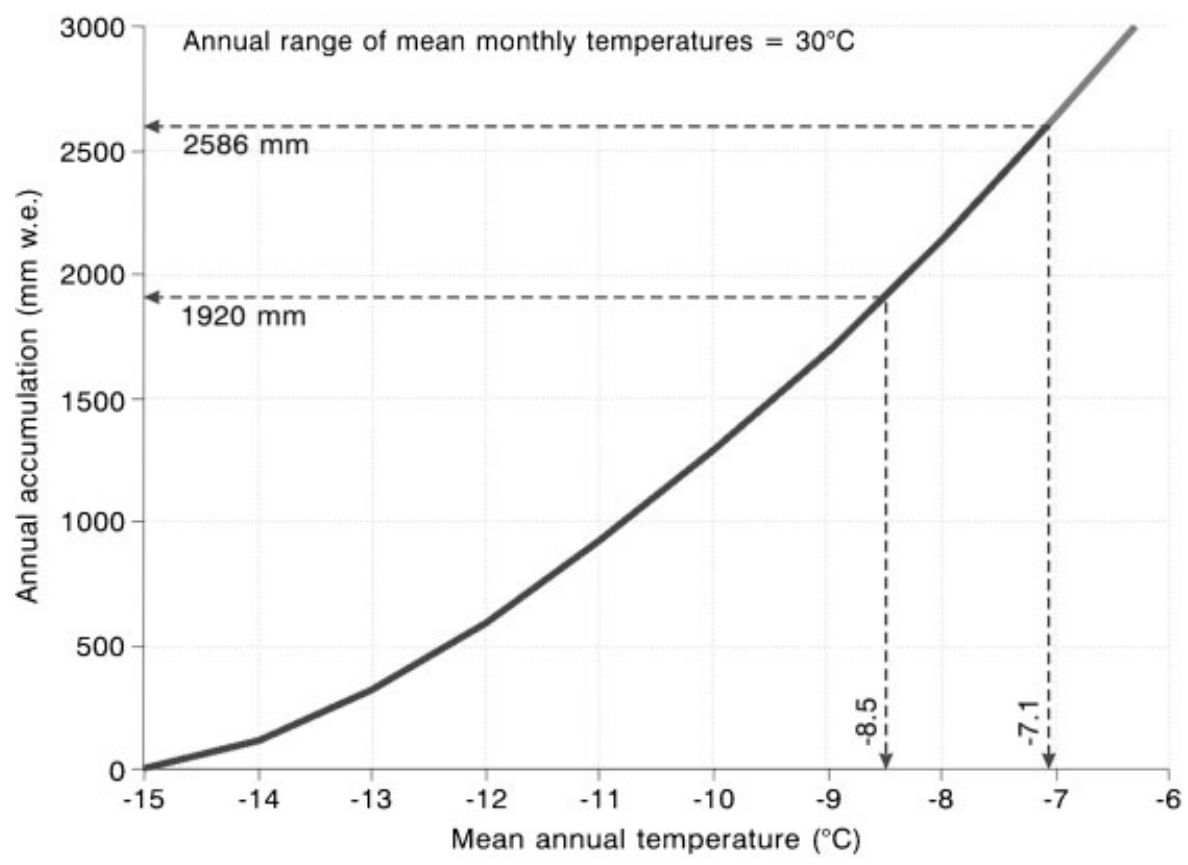

Figure 8. Values of annual accumulation calculated using a simple degree-day model based on mean annual temperatures at the highest and lowest ELAs of former glaciers in the Aran and Berwyn mountains. The amount of snow melt per day can then be calculated using a degree-day factor of $4 \mathrm{~mm} \mathrm{day}^{-1}{ }^{\circ} \mathrm{K}^{-1}$ (Braithwaite et al. 2006) and the annual accumulation required at the ELA to balance melting equals the annual sum of daily snow melt. Mean annual temperatures are derived from July temperature values at sea level based on Coleopteran data from Llanilid in South Wales (Walker et al. 2003). Mean July temperatures were converted to mean annual temperatures by distributing mean monthly temperatures over a sine curve with an annual range of $30^{\circ} \mathrm{C}$ (Isarin et al. 1998) and extrapolated to the ELAs of the former glaciers using a lapse rate of $0.6^{\circ} \mathrm{C} / 100 \mathrm{~m}$.

and above any glaciers on Cadair Idris. This is consistent with an inland precipitation gradient with the lowest precipitation on the Berwyns forcing higher ELAs.

In Northwest Wales, Loch Lomond Stadial glaciers also show a clear trend of increasing ELAs from southwest to northeast, suggesting a strong precipitation gradient (Gray 1982). However, in the Berwyns, the Cwm Dwygo glacier was remarkably low compared with other Loch Lomond Stadial glaciers in North Wales and only two other glaciers, at Cwm Drws-y-Coed in the Nantlle Hills (Gray 1982), and at Cwm Orthin in the Moelwyns (Lowe 1993), had ELAs lower than at Cwm Dwygo. The obvious first response is to suggest that the Cwm Dwygo is older than the glaciers elsewhere in the Berwyns and formed prior to the Loch Lomond Stadial, between $c .14{ }^{14} \mathrm{C}$ ka BP associated with Heinrich Event I in the North Atlantic and the climate amelioration of the Windermere Interstadial which began at $c .13{ }^{14} \mathrm{C}$ ka BP. Glacier occupation pre-dating the Loch Lomond Stadial may be suggested by the presence of what may be a pronival rampart close to the cirque backwall, which may itself date to this interval. However, Cwm Dwygo had the largest snowblow ratio of all the glaciers in the Aran and Berwyn mountains and thus, a low ELA during the Loch Lomond Stadial can be explained as the result of substantial extra accumulation from windblown snow. The Cwm Dwygo glacier had a snowblow ratio of 3.2-more than twice the snowblow ratio at Llyn Lluncaws and the highest in the Arans and Berwyns combined (Table 1).

Across Wales, there were several other anomalously low former glaciers, such as in the Pumlumon and Elenydd regions (Table 4), and these too are likely to have been influenced by wind blown snow accumulation during the Loch Lomond Stadial. However, low-lying localized glaciers in South Wales, such as in cirques near Abergavenny and in the Black Mountains (Table 4), were situated beyond the margins of the last ice sheet over Wales and may well have formed prior to the Loch Lomond Stadial. 
Table 4. List of former localized cirque glaciers in Wales

\begin{tabular}{|c|c|c|c|c|}
\hline & Mountain area & Site name & Source & ELA \\
\hline 1 & Nantlle & Cwm Silin & Gray (1982) & 430 \\
\hline 2 & Nantlle & Cwm-y-Ffynnon & Gray (1982) & 475 \\
\hline 3 & Nantlle & Cwm Drws-y-Coed & Gray (1982) & 410 \\
\hline 4 & Snowdon & Cwm-y-Hafod & Gray (1982) & 540 \\
\hline 5 & Snowdon & Cwm Dwythwch 1 & Gray (1982) & 475 \\
\hline 6 & Snowdon & Cwm Dwythwch 2 & Gray (1982) & 470 \\
\hline 7 & Snowdon & Cwm Du'r Arddu & Gray (1982) & 655 \\
\hline 8 & Snowdon & Cwm Glas Mawr & Gray (1982) & 440 \\
\hline 9 & Snowdon & Cwm Ffynnon-y-Gwas & Gray (1982) & 480 \\
\hline 10 & Snowdon & Cwm Clogwyn & Gray (1982) & 530 \\
\hline 11 & Snowdon & Cwm Tregalan & Gray (1982) & 680 \\
\hline 12 & Snowdon & Cwm Dyli & Gray (1982) & 590 \\
\hline 13 & Glyders & Marchlyn Bach & Gray (1982) & 570 \\
\hline 14 & Glyders & Marchlyn Mawr & Gray (1982) & 690 \\
\hline 15 & Glyders & Cwm Graianog & Gray (1982) & 585 \\
\hline 16 & Glyders & Cwm Bual & Gray (1982) & 605 \\
\hline 17 & Glyders & Cwm Coch & Gray (1982) & 550 \\
\hline 18 & Glyders & Cwm Cywion & Gray (1982) & 690 \\
\hline 19 & Glyders & Cwm Clyd & Gray (1982) & 785 \\
\hline 20 & Glyders & Cwm Idwal & Gray (1982) & 510 \\
\hline 21 & Glyders & Cwm Bochllwyd & Gray (1982) & 690 \\
\hline 22 & Glyders & Cwm Tryfan & Gray (1982) & 610 \\
\hline 23 & Glyders & Cwm y Gors & Gray (1982) & 415 \\
\hline 24 & Carneddau & Cwm Lloer & Gray (1982) & 755 \\
\hline 25 & Carneddau & Cwm Llugwy & Gray (1982) & 695 \\
\hline 26 & Carneddau & Cwm Bychan & Gray (1982) & 710 \\
\hline 27 & Carneddau & Pen Llithrig-y-Wrach & Gray (1982) & 530 \\
\hline 28 & Carneddau & Cwm Eigiau & Gray (1982) & 530 \\
\hline 29 & Carneddau & Cwm Glas Mawr & Gray (1982) & 680 \\
\hline 30 & Carneddau & Cwm Glas Bach & Gray (1982) & 730 \\
\hline 31 & Carneddau & Cwm Caseg & Gray (1982) & 815 \\
\hline 32 & Carneddau & Melynlyn & Gray (1982) & 710 \\
\hline 33 & Carneddau & Cwm Dulyn & Gray (1982) & 675 \\
\hline 34 & Carneddau & Cwm Anafon & Gray (1982) & 630 \\
\hline 35 & Moel Siabod \& Moelwyns & Cwm Siabod & Gray (1982) & 635 \\
\hline 36 & Moel Siabod \& Moelwyns & Moelwyn Mawr ${ }^{\S}$ & Lowe (1993) & 531 \\
\hline 37 & Moel Siabod \& Moelwyns & Cwm Orthin & Lowe (1993) & 414 \\
\hline 38 & Arenigs & Cwm Gylchedd & Hughes (2002) & 531 \\
\hline 39 & Arenigs & Llyn Arenig Fach & Hughes (2002) & 511 \\
\hline 40 & Arenigs & Llyn Arenig Fawr & Hughes (2002) & 470 \\
\hline 41 & Arans & Gwaun-y-Llwyni & Hughes (this paper) & $510^{\dagger}$ \\
\hline 42 & Arans & Y Gribin & Hughes (this paper) & $500^{\dagger}$ \\
\hline 43 & Arans & Llyn Lliwbran & Hughes (2002) & 503 \\
\hline 44 & Berwyns & Cwm Llawenog & Hughes (this paper) & $660^{\dagger}$ \\
\hline 45 & Berwyns & Llyn Lluncaws & Hughes (this paper) & $646^{\dagger}$ \\
\hline 46 & Berwyns & Cwm Dwygo & Hughes (this paper) & $429^{\dagger}$ \\
\hline 47 & Cadair Idris & Cwm Gadair & Lowe (1993) & 622 \\
\hline 48 & Cadair Idris & Twr Du & Lowe (1993) & 620 \\
\hline 49 & Cadair Idris & Cwm Cau & Lowe (1993) & 560 \\
\hline 50 & Pumlumon and Elenydd & Cwm Rhiwgam & Cave and Hains (1986) & $340^{\dagger}$ \\
\hline 51 & Pumlumon and Elenydd & Llyn Llygad Rheidol & Watson (1969) & $570^{\dagger}$ \\
\hline 52 & Pumlumon and Elenydd & Cwm Du & Watson $(1966,1969)^{*}$ & $420^{\dagger}$ \\
\hline 53 & Pumlumon and Elenydd & Cwm Tinwen & Watson $(1966,1969)^{*}$ & $410^{\dagger}$ \\
\hline
\end{tabular}


Table 4. (Continued)

\begin{tabular}{|c|c|c|c|c|}
\hline & Mountain area & Site name & Source & ELA \\
\hline 54 & Mynydd Du and Fforest Fawr & Craig-y-Fro & Robertson (1989) & 426 \\
\hline 55 & Mynydd Du and Fforest Fawr & Craig Cerrig-gleisiad & Carr and Coleman (2007a) & $486^{\ddagger}$ \\
\hline 56 & Mynydd Du and Fforest Fawr & Fan Bwlch Chwyth & Robertson (1989) & $474^{\ddagger}$ \\
\hline 57 & Mynydd Du and Fforest Fawr & Llyn y Fan Fach & Robertson (1989) & $576^{\ddagger}$ \\
\hline 58 & Mynydd Du and Fforest Fawr & Cwm Sychlwch & Carr et al. (2007) & $643^{\ddagger}$ \\
\hline 59 & Mynydd Du and Fforest Fawr & Gwal y Cadno & Robertson (1989) & $703^{\ddagger}$ \\
\hline 60 & Mynydd Du and Fforest Fawr & Fan Hir & Shakesby and Matthews (1993) & 623 \\
\hline 61 & Brecon Beacons & Cwm Milan & Carr $(2001)$ & $548^{\ddagger}$ \\
\hline 62 & Brecon Beacons & Cwm Llwch & Carr (2001) & $610^{\ddagger}$ \\
\hline 63 & Brecon Beacons & Cwm Gwaun Taf & Carr (2001) & $758^{\ddagger}$ \\
\hline 64 & Brecon Beacons & Cwm Crew & Carr (2001) & $700^{\ddagger}$ \\
\hline 65 & Brecon Beacons & Cwm Oergwm & Robertson (1989) & $599^{\ddagger}$ \\
\hline 66 & Brecon Beacons & Cwm Pwlffa & Preston et al. (2007) & $645^{\ddagger}$ \\
\hline 67 & Brecon Beacons & Nant Tarthwynni & Carr and Coleman (2007b) & $620^{\ddagger}$ \\
\hline 68 & Abergavenny and Black Mountains & Tarren yr Esgob & Robertson (1989) & $443^{\ddagger}$ \\
\hline 69 & Abergavenny and Black Mountains & Punchbowl & Barclay (1989) & $340^{\dagger}$ \\
\hline 70 & Abergavenny and Black Mountains & Craig-y-Hafod & Barclay (1989) & $350^{\dagger}$ \\
\hline 71 & Abergavenny and Black Mountains & Graig-y-Cwm & Barclay (1989) & $290^{\dagger}$ \\
\hline 72 & Craig-y-Llyn & Llyn Fach & Barclay et al. (1988) & $480^{\dagger}$ \\
\hline 73 & Craig-y-Llyn & Llyn Fawr & Barclay et al. (1988) & $450^{\dagger}$ \\
\hline
\end{tabular}

All of these sites contain moraines or other landforms indicative of local glacier occupation. The majority of these sites have been, or can be, correlated with the Loch Lomond Stadial, since they exist in areas well within the margins of the last Welsh Ice Sheet and probably also within retreat limits such as during Heinrich Event I, when at least large valley glaciers would have occurred in parts of Wales, based on observations elsewhere around the Irish Sea basin ( $c f$. McCabe et al. 1998; McCabe and Dunlop 2006). However, some sites may represent earlier local cirque glacier occupation, especially the low cirques of Southeast Wales, which are situated close to the margins of the maximum extent of the Welsh Ice sheet of the Devensian cold stage.

*Interpreted by Watson (1966) as a nivation hollow but later re-interpreted as the product of glacier ice by Potts (1971) and Ballantyne and Harris (1994, p. 246).

${ }^{\dagger}$ ELAs estimated for the purposes of this study using a simple toe to headwall ratio of 0.4.

${ }^{\ddagger}$ ELAs calculated using the mean of several methods. Unless indicated, all other ELAs are calculated using the area-weighted mean altitude method of Sissons (1974).

${ }^{\S}$ Glacier site, later occupied by a rock glacier during retreat (Lowe 1993).

When examining the wider dataset of cirques in Wales it becomes clear that the ELAs of over 70 cirque glacier sites, the majority of possible Loch Lomond Stadial age, lie within an altitudinal range of less than $500 \mathrm{~m}$ with ELAs of 340-815 m (discounting the lowest cirque moraines in South Wales, which could potentially pre-date the Loch Lomond Stadial-see Table 4 caption). Spatial variability of ELAs across Wales is likely to be due to differences in local controls, as well as regional precipitation gradients, and further work is necessary to model the palaeoglacier-climate patterns. The presence of the new local glacier sites in the Arans and Berwyns and the possibility of many other sites across Wales (Evans 2006), where glaciers of Loch Lomond Stadial age have not yet been reconstructed, suggests that the inventory of Loch Lomond Stadial glaciers in Wales may not yet be complete, more than 160 years after the early observations of glacial landforms by Darwin (1842) in Snowdonia.

The regression approach of Ohmura et al. (1992) suggests that the combined value of summer precipitation + winter balance at the ELAs of the Aran and Berwyn glaciers would have been in the range of 2428-2985 mm w.e. (Table 3). The winter balance component is likely to include some element of local accumulative input from windblown snow, as noted above, especially on the lowest glacier at Cwm Dwygo. Consequently, the lower end of this range ( $2428 \mathrm{~mm}$ w.e.) is likely to be nearer to the value of annual precipitation. The degree-day model predicts that accumulation values in the range of 1920-2586 $\mathrm{m}$ w.e. (Table 3; Figure 8). Again, the lower value is most likely to be representative of accumulation input derived from direct precipitation. The average modern annual precipitation value over the period of 1995-2000 at Lake Vyrnwy $(360 \mathrm{~m})$, situated between the Arans and the 
Berwyns, was $1672 \mathrm{~mm}$ (Meteorological Office 2008) and precipitation is estimated to be over $2000 \mathrm{~mm}$ on the highest hills (Tallis 1969). Thus, annual accumulation on the former Aran and Berwyn glaciers during the Loch Lomond Stadial glacier maximum appears to have been similar to modern-day values of annual precipitation (Table 3). This finding is similar to those from western Scotland, where glacier-climate reconstructions using the regression model of Ohmura indicate inferred precipitation values similar to, or slightly greater than, modern values (Ballantyne 2002, 2007a,b).

The sustained levels of precipitation (similar to or greater than modern values) in the mountains of western Britain is likely to have been the result of active depressions close to the Polar Front, which was situated at latitude c. $45-50^{\circ} \mathrm{N}$, to the southwest of the British Isles at this time (Ruddimann and McIntyre 1981). A stormy and more southerly track of depressions over the British Isles during the Loch Lomond Stadial was recognized by Sissons (1979) and this is supported by evidence of a strong thermal gradient south of the Polar Front (Ruddimann and McIntyre 1981). However, glacier response to the climate signal may have been complex, especially since Walker (2004) has presented pollen evidence of a cold and wet early phase of the Loch Lomond Stadial followed by a cold and dry later phase, at Hallsenna Moor in northwest England. Thus, the evidence from the Arans and Berwyns of wet and cold conditions during glaciation would seem to suggest that the glaciers must have reached their maximum in the wet and cold early phase of the Loch Lomond Stadial.

Modern analogues representative of the former Aran and Berwyn glaciers are elusive. The combinations of summer temperature and accumulation (or winter balance + summer precipitation) are similar to those at the ELAs of glaciers in the North American Cordillera and Scandinavia (Ohmura et al. 1992). However, the climate at the former Aran and Berwyn glaciers was calculated using an annual temperature range of $30^{\circ} \mathrm{C}$ (Isarin et al. 1998) which is greater than for most glaciers in these two analogue regions. This temperature range effectively means that winter temperatures would have been much more severe in Wales during the Loch Lomond Stadial compared with modern-day Cordilleran and Scandinavian glaciers that exist under similar summer temperatures to the former Welsh glaciers. Most Scandinavian glaciers are warm based and only a few are cold based and/or polythermal (Whalley 2004). Much colder winters during Loch Lomond Stadial in Wales, yet similar summer temperatures combined with accumulation/precipitation values when compared to modern Scandinavian glaciers, may be favourable for polythermal glaciers. Indeed, evidence of polythermal glacier dynamics during the Loch Lomond Stadial in Wales has been presented by Graham and Midgley (2000). However, further investigation is needed to test this possibility and also in order to find suitable modern analogues, if they exist, for Loch Lomond Stadial glaciers in Wales.

\subsection{Glacier-climate reconstruction: comparing the regression and degree-day model approaches}

The range of values reconstructed using the Ohmura et al. regression and degree-day model approaches are different. This is partly because the two approaches predict different things; the regression: summer precipitation + winter balance; and the degree-day model: annual accumulation. Thus, it may be expected that the former produces higher values than the latter, since it includes summer precipitation which is likely to fall as rain. However, it is not sufficient to infer that the difference between the values predicted by the two approaches simply represents a summer rainfall component. This is illustrated in Figure 9, which plots the difference in values of summer precipitation + winter balance and annual accumulation predicted using the regression and degree-day model approaches. Under an annual range of $30^{\circ} \mathrm{C}$, the difference between the values of summer precipitation + winter balance and annual accumulation increases as summer temperatures decrease from $c .10$ to $3^{\circ} \mathrm{C}$. At summer temperatures lower than $3^{\circ} \mathrm{C}$ the difference between the values of summer precipitation + winter balance and annual accumulation decreases again. The same pattern is true at lower temperature ranges although the slope of the curve becomes increasingly steeper. This asymmetrical reverse U-shaped pattern is derived because at low summer temperatures a significant proportion of summer precipitation is likely to fall as snow. As summer temperatures increase, then an increasing amount of precipitation in this season falls as rain. As summer temperatures rise further still, then the summer melt season predicted by the degree-day model becomes progressively longer, increasing the amount of accumulation necessary to balance melting. Thus, there is a convergence of the values of summer 


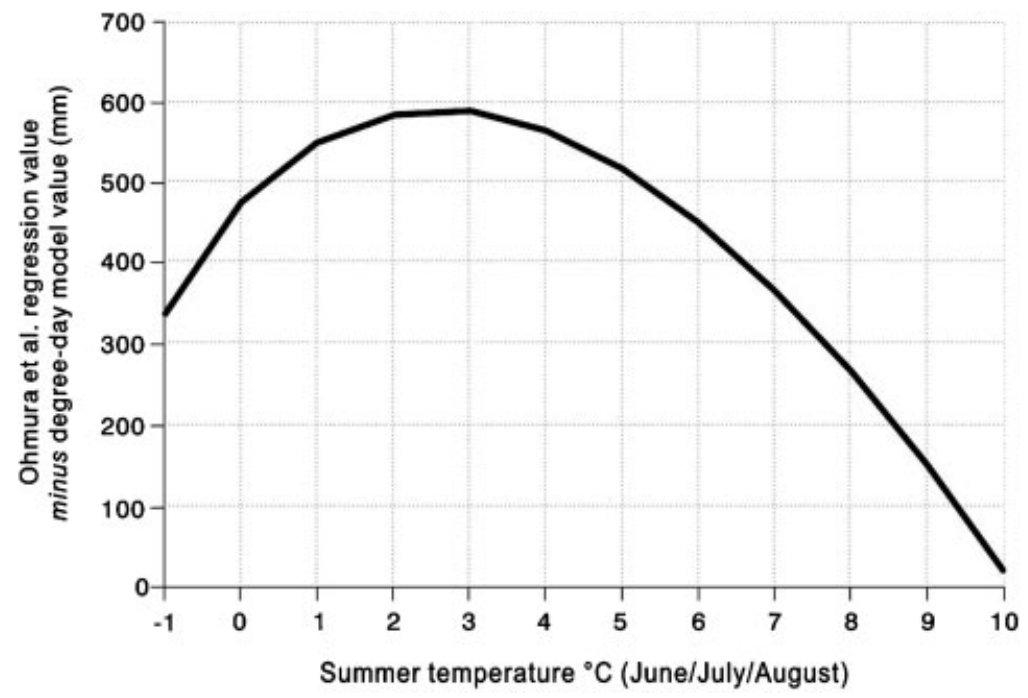

Figure 9. Graph showing the difference between values of winter balance + precipitation calculated using the regression equation of Ohmura et al. (1992) and values of annual accumulation calculated using a simple degree-day model, at given summer temperatures under an annual range of $30^{\circ} \mathrm{C}$. See text for more details.

precipitation + winter balance and annual accumulation predicted by the Ohmura regression and the degree-day model when mean summer temperatures increase (Figure 9). Under high summer temperatures (above $10^{\circ} \mathrm{C}$ when annual range is $30^{\circ} \mathrm{C}$, and at progressively lower mean summer temperatures when annual range is $<30^{\circ} \mathrm{C}$ ), values of summer precipitation + winter balance predicted by the Ohmura et al. regression are lower than that predicted for the degree-day model — which would be illustrated by a negative difference in Figure 9. This reflects the fact that the Ohmura et al. regression is based on real observations of glaciers and climate, and once summer temperatures become very high, even under high annual ranges, this results in winters too warm for snow to fall. For this reason, a linear regression is perhaps not suitable to describe the relationship between summer temperature + winter balance and summer temperature. Indeed, Braithwaite (2008) has shown that this relationship can also be described by exponential and power-law curves, which provide a more realistic representation of summer precipitation + winter balance and summer temperature combinations at low and high temperatures.

\section{CONCLUSIONS}

Climate reconstruction at the ELA of former cirque glaciers in the Aran and Berwyn mountains, North Wales, indicates a cold and wet climate during the Loch Lomond Stadial. The Aran and Berwyn glaciers had ELAs in the range of 429-660 m. The two easternmost glaciers, in the Berwyns, had ELAs well above those in the Arans and Arenigs and above any glaciers on Cadair Idris to the west. However, a low elevation cirque glacier present at Cwm Dwygo in the western Berwyns can be explained by substantially greater quantities of extra accumulation from windblown snow than at the other glacier sites. The presence of these glacier sites, some of which have never been documented before, illustrates the incomplete nature of the Loch Lomond Stadial glacier inventory in Wales. A degree-day model predicts that annual accumulation of 1920-2586 mm w.e. would have been required to offset ablation, whilst a regression approach (Ohmura et al. 1992) predicts a value of $2428-2985 \mathrm{~mm}$ w.e. for summer precipitation + winter balance. The difference between values of accumulation and summer precipitation + winter balance calculated by the degree-day model and a regression-based approach is determined by summer temperatures and also annual temperature range, since these control the proportion of precipitation that falls as rain or snow. 


\section{ACKNOWLEDGEMENTS}

The author thanks Colin Ballantyne (University of St Andrews, Scotland), Ian Evans (University of Durham, England), Mike Hambrey (Aberystwyth University) and Mike Walker (University of Wales, Lampeter) for very useful and helpful comments on a draft of this manuscript. The author also thanks Dr Roger Braithwaite (University of Manchester, England) for very helpful discussions on glacier-climate modelling.

\section{REFERENCES}

Ballantyne CK. 1989. The Loch Lomond Readvance on the Isle of Skye, Scotland: glacier reconstruction and palaeoclimatic implications. Journal of Quaternary Science 4: 95-108.

Ballantyne CK. 2002. The Loch Lomond Readvance on the Isle of Mull, Scotland: glacier reconstruction and palaeoclimatic implications. Journal of Quaternary Science 17: 759-771.

Ballantyne CK. 2007a. The Loch Lomond Readvance on north Arran, Scotland: glacier reconstruction and palaeoclimatic implications. Journal of Quaternary Science 22: 343-359.

Ballantyne CK. 2007b. Loch Lomond Stadial glaciers in North Harris, Outer Hebrides, North-West Scotland: glacier reconstruction and palaeoclimatic implications. Quaternary Science Reviews 26: 3134-3149.

Ballantyne CK, Benn DI. 1994. Glaciological constraints on protalus rampart development. Permafrost and Periglacial Processes 5: $145-153$.

Ballantyne CK, Harris C. 1994. The Periglaciation of Great Britain. Cambridge University Press, Cambridge; 340.

Barclay WJ. 1989. Geology of the South Wales Coalfield, Part II. The country around Abergavenny (3rd edn). H.M. Stationery Office: London. British Geological Survey (Memoir for England and Wales Sheet 232).

Barclay WJ, Taylor K, Thomas LP. 1988. Geology of the South Wales Coalfield, Part V. The country around Merthyr Tydfil (3rd edn). H.M. Stationery Office: London. British Geological Survey (Memoir for England and Wales Sheet 231).

Benn DI, Ballantyne CK. 2005. Palaeoclimatic reconstruction from Loch Lomond Readvance glaciers in the West Drumochter Hills, Scotland. Journal of Quaternary Science 20: 577-592.

Bradley RS, England JH. 2008. The Younger Dryas and the sea of ancient ice. Quaternary Research 70: 1-10.

Braithwaite RJ. 2008. Temperature and precipitation climate at the equilibrium-line altitude of glaciers expressed by the degree-day factor for melting snow. Journal of Glaciology 54: 437-444.

Braithwaite RJ, Raper SCB, Chutko K. 2006. Accumulation at the equilibrium line altitude of glaciers inferred from a degree-day model and tested against field observations. Annals of Glaciology 43: 329-334.

Brugger KA. 2006. Late Pleistocene climate inferred from the reconstruction of the Taylor River glacier complex, southern Sawatch Range, Colorado. Geomorphology 75: 318-329.

Carr SJ. 2001. A glaciological approach for the discrimination of Loch Lomond Stadial glacial landforms in the Brecon Beacons, South Wales. Proceedings of the Geologists' Association 112: 253-262.

Carr SJ, Coleman CG. 2007a. Form, mass-balance and dynamics of the Craig Cerrig-gleisiad glacier. In Quaternary of the Brecon BeaconsField Guide, Carr SJ, Coleman CG, Humpage AJ, Shakesby RA (eds). Quaternary Research Association: London; 139-141.

Carr SJ, Coleman CG. 2007b. The Waun Rydd plateau. In Quaternary of the Brecon Beacons-Field Guide, Carr SJ, Coleman CG, Humpage AJ, Shakesby RA (eds). Quaternary Research Association: London; 246-249.

Carr SJ, Coleman CG, Evans DJA, Porter EM, Rea BR. 2007. Glacier reconstruction and energy balance modelling of scarp-foot landforms at the Mynydd Du (Black Mountain). In Quaternary of the Brecon Beacons-Field Guide, Carr SJ, Coleman CG, Humpage AJ, Shakesby RA (eds). Quaternary Research Association: London; 57-65.

Cave R, Hains B. 1986. Geology of the country between Aberystwyth and Machynlleth. H.M. Stationery Office: London. British Geological Survey (Memoir for England and Wales Sheet 163).

Cope TH. 1915. On the igneous and pyroclastic rocks of the Berwyn Hills (North Wales). Proceedings of the Liverpool Geology Society, Cope Memorial Volume; 115.

Dahl SO, Nesje A, Ovestal J. 1997. Cirque glaciers as morphological evidence for a thin Younger Dryas ice-sheet in east-central southern Norway. Boreas 26: 163-179.

Darwin CR. 1842. Notes on the effects produced by the ancient glaciers of Caernarvonshire, and on the boulders transported by floating ice. London, Edinburgh and Dublin Philosophical Magazine and Journal of Science 21: 180-188.

Evans IS. 2006. Allometric development of glacial cirque form: geological, relief and regional effects on the cirques of Wales. Geomorphology 80: $245-266$.

Evans IS, Cox NJ. 1974. Geomorphometry and the operational definition of cirques. Area 6: 150-153.

Furbish DJ, Andrews JT. 1984. The use of hypsometry to indicate long-term stability and response of valley glaciers to changes in mass transfer. Journal of Glaciology 30: 199-211.

Graham DJ, Midgley NG. 2000. Moraine-mound formation by englacial thrusting: the Younger Dryas moraines of Cwm Idwal, North Wales. In Deformation of Glacial Materials, Maltman AJ, Hambrey MJ, Hubbard B (eds). Geological Society: London; 321-336.

Gray JM. 1982. The last glaciers (Loch Lomond Advance) in Snowdonia, North Wales. Geological Journal 17: 111-133.

Harrison S, Anderson E, Patel D. 2006. The eastern margin of glaciation in the British Isles during the Younger Dryas: the Bizzle cirque, southern Scotland. Geografiska Annaler 88A: 199-207.

Hughes PD. 2002. Loch Lomond stadial glaciers in the Aran and Arenig mountains, North Wales, Great Britain. Geological Journal 37: 9-15. 
Hughes PD, Braithwaite RJ. 2008. Application of a degree-day model to reconstruct Pleistocene glacial climates. Quaternary Research 69: $110-116$.

Ince J. 1983. Two postglacial pollen profiles from the uplands of Snowdonia, Gwynedd, North Wales. New Phytologist 95: 159-172.

Ince J. 1990. Late-glacial and early Holocene vegetation of Snowdonia. New Phytologist 132: 343-353.

Isarin RFB, Renssen H, Vandenberghe J. 1998. The impact of the North Atlantic Ocean on the Younger Dryas climate in northwestern and central Europe. Journal of Quaternary Science 13: 447-453.

Lomas J. 1908. The geology of the Berwyn Hills. Proceedings of the Geologists' Association 20: 477-500.

Lowe S. 1993. The Devensian Lateglacial and Early Flandrian Stratigraphy of Southern Snowdonia, North Wales. PhD Thesis, University of London.

McCabe AM, Dunlop P. 2006. The last glacial termination in Northern Ireland. Geological Survey of Northern Ireland, Belfast. 93.

McCabe M, Knight J, McCarron S. 1998. Evidence for Heinrich Event 1 in the British Isles. Journal of Quaternary Science 13: 549-568.

Meteorological Office. 2008. Climate data for Lake Vyrnwy No. 2. (1995-2000). Data available on request from http://www.metoffice.gov.uk/ corporate/contact/contact.html [09 October 2008].

Mitchell WA. 1988. Significance of snowblow in the generation of Loch Lomond Stadial (Younger Dryas) glaciers in the western Pennines, northern England. Journal of Quaternary Science 11: 233-248.

Ohmura A, Kasser P, Funk M. 1992. Climate at the equilibrium line of glaciers. Journal of Glaciology 38: 397-411.

Phillips FM, Bowen DQ, Elmore D. 1994. Surface exposure dating of glacial features in Great Britain using cosmogenic chlorine-36: preliminary results. Mineralogical Magazine 58A: 722-723.

Porter SC. 1975. Equilibrium-line altitudes of late quaternary glaciers in the Southern Alps, New Zealand. Quaternary Research 5: $27-47$.

Potts AS. 1971. Fossil cryonival features in Wales. Geografiska Annaler 53: 39-51.

Preston G, Carr SJ, Coleman CG, Parker AG. 2007. Cwm Pwlffa. In Quaternary of the Brecon Beacons -Field Guide, Carr SJ, Coleman CG, Humpage AJ, Shakesby RA (eds). Quaternary Research Association: London; 240-245.

Robertson DW. 1989. Aspects of the Lateglacial and Flandrian environmental history of the Brecon Beacons, Fforest Fawr, Black Mountain, South Wales (with emphasis on the Lateglacial and Early Flandrian periods). PhD Thesis, University of Wales.

Ruddimann WF, McIntyre A. 1981. The North Atlantic Ocean during the last deglaciation. Palaeogeography, Palaeoclimatology, Palaeoecology 35: 145-214.

Shakesby RA, Matthews JA. 1993. The Loch Lomond stadial at Fan Hir, Mynydd Du (Brecon Beacons), South Wales: critical evidence and palaeoclimatic implications. Geological Journal 28: 69-79.

Shennan I, Horton B. 2002. Holocene land - and sea-level changes in Great Britain. Journal of Quaternary Science 17: 511-526.

Sissons JB. 1974. A Lateglacial ice-cap in the central Grampians, Scotland. Transactions of the Institute of British Geographers 62: 95-114.

Sissons JB. 1979. Palaeoclimatic inferences from former glaciers in Scotland and the Lake District. Nature 278: 518-521.

Sissons JB, Sutherland DG. 1976. Climatic inferences from former glaciers in the South-East Grampian Highlands, Scotland. Journal of Glaciology 17: 325-346.

Sutherland DG. 1984. Modern glacier characteristics as a basis for inferring former climates with particular reference to the Loch Lomond stadial. Quaternary Science Reviews 3: 291-309.

Tallis JH. 1969. The blanket bog vegetation of the Berwyn mountains, North Wales. The Journal of Ecology 57: $765-787$.

Travis CB. 1944. The glacial history of the Berwyn hills, North Wales. Proceedings of the Liverpool Geological Society 19: 14-28.

Walker MJC. 1980. Late-glacial history of the Brecon Beacons, South Wales. Nature 287: 133-135.

Walker MJC. 2004. A Lateglacial pollen record from Hallsenna Moor, near Seascale, Cumbria, with evidence for increased aridity during the later Loch Lomond stadial and early Holocene. Proceedings of the Yorkshire Geological Society 55: 33-42.

Walker MJC, Coope GR, Sheldrick C, Turney CSM, Lowe JJ, Blockley SPE, Harkness DD. 2003. Devensian Lateglacial environmental changes in Britain: a multi-proxy environmental record from Llanilid, South Wales, UK. Quaternary Science Reviews 22: 475-520.

Walker R. 1978. Diatom and pollen studies of a sediment profile from Melynllyn, a mountain tarn in Snowdonia, North Wales. New Phytologist 81: 791-804.

Watson E. 1966. Two nivation cirques near Aberystwyth, Wales. Biuletyn Peryglacjalny 15: 95-113.

Watson E. 1969. The periglacial landscape of the Aberystwyth region. In Geography at Aberystwyth, Bowen EG, Carter H, Taylor JA (eds). University of Wales Press: Cardiff; 35-40.

Whalley WB. 2004. Glacier research in mainland Scandinavia. In Earth Paleoenvironments: records preserved in mid-and low-latitude glaciers, DeWayne Cecil L, Green JR, Thompson LG (eds). Kluwer Academic Publishers, Dordrecht: 121-143.

Scientific editing by Brian Williams 